\title{
IMAGES OF BIRDS IN MORDVINIAN MYTHOLOGY
}

\author{
Tatiana Deviatkina
}

\begin{abstract}
The article focuses on various functions of birds appearing as an indispensable element of the mythological system. First of all, their role is underlined in the cosmogonic and anthropogonic act. The most archaic is the image of the Great Bird, the creator of the world and man (among MordviniansErzians). Mention is made about the role of prophetic birds and their use in the capacity of sacrifice and rituals. Gods and deities presented themselves in images of different birds (duck, eagle, pigeon, swan, swallows etc.). Some comparisons with other Finno-Ugric ethnoses (Mari, Komi etc.) are given.
\end{abstract}

Key words: anthropogony, birds, cosmogony, gods and deities in the image of birds, Mordvinians (Mokshans and Erzians), mythology, prophetic birds, sacrifice

Images of birds occupy a particular place in the mythology of Mordvinians, and among other peoples. However, the subject matter presented in the article has so far not received the due attention of researchers. Birds appear as an indispensable element of the mythological system and perform different functions. First of all, it is essential to describe their cosmogonic and anthropogonic functions.

The image of the Great Bird (mdM Ine Narmon', mdE Ine Narmun') is the most archaic in Mordvinian mythology where she acts as the creator of the world. Thus, she lays the Great World Egg (mdE Ine Al, mdM Otsiu Al), from which the world appears. The Earth comes from the egg-yolk, while the sky and the underground solidity emerge from the eggshell.

A similar motif, the creation of the world from an egg laid by a bird, is typical in the cosmogony of other Finno-Ugric peoples: Finns, Estonians, Saami, Komi (Myths 1994: 564). Likewise, in Mordvinian mythology, the Great Bird is the original mother of some ethnoses and deities. According to a Mordvinian myth, the forefathers of Erzians-Mordvinians, Russians and Chuvashs were born from the three eggs of the Great Bird. Similarly, deities-patronesses of fertility - Norovava (mdE), wind - Varmava (mdM, mdE), woods - Vir'ava (mdM, mdE) were hatched out of three eggs laid by Ine Narmun' (mdE) in the nest on 
an unusual birch (Harva 1952: 141) which grew in the centre of the Earth. Three branches of the birch formed the tree-top, and three forks - its root. The birch was found by the Great Bird (God's messenger) - Ine Narmon' (mdM), who built a nest in the tree-top, laid three eggs, hatched them, and out came the three sisters-deities.

The image of a duck (mdM iaksiarga, mdE iaksiargo) is no less popular in the world creation's myths. According to preserved Mordvinian materials, she is notable for her unusual beauty, her physical description is full of mythological symbols: she has gilded legs; a coin-like patterned design appears on her wings, which have golden edges; her feathering resembles coins; there are tsar's signets (divine signs) on her back; her head is silvery; her beak and feet are made of copper; her wings are crescent-shaped (UPTMN 1963: 159). She radiates unusual light, being majestic and sublime. According to myths, once a God (it is unknown whether the Mokshan or Erzian one) swam in the ocean in the shape of a duck. At first, there was water everywhere, and the God had dived to the bottom of the ocean, taken a lump of earth in his beak, spat it out (UPTMN 1983: 188), and the latter began to grow and increase. Thus the Earth was created.

At the request of the Supreme God of Mokshas-Mordvinians the same image of a duck is assumed by deuce Shaitan (mdM), with the task of diving deepdown to the bottom of the sea in order to get construction material (soil, sand) for creating the Earth. This myth undoubtedly belongs to the apocryphal type. The mythological plots of the Erzians of the Samara province tell that Shaitan was born by Chipaz - the Supreme God of the Sun - the devil came out from the Chipaz' spit produced in vexation and his stroke with the staff (Pecherskii 1986: 45). The Moksha-Mordvinian Supreme God (Shkai) gives soul to Shaitan. However, he could not breathe it into Shaitan and instead puts the soul on his face. Then the God (Shkai) moves this soul into a duck and let her swim in the Great Ocean which surrounded the whole Earth. Shaitan agrees to help Chipaz to create the world out of the sand that he had brought up (after changing into a duck) (Pecherskii 1986: 53) from the bottom of the sea. However, the devil does not follow precisely Chipaz's directions (because of his pride), and the God curses him and sends him to hell under the bottom of the sea (Pecherskii 1986: 47).

In other Finno-Ugric myths, the God-Demiurg (En - in Komi; Kugu - in Mari, Inmar - Udmurt, Numi-Torum - among the Ob-Ugrians) orders an aquatic bird or his junior brother appearing like a bird (Omol' - Komi, Keremet - Mari and Udmurt, Kul'-otyr - Mansi), who swam in the primeval ocean to get a lump of earth from the depths. From this lump of earth the God creates the Earth and all that is useful on it, while his brother (in the Mordvinian case the devil) creates mountains and all that is harmful, from the sand concealed in his mouth (Myths 1994: 564). 
The Mordvinian mythological duck image is also associated with people - the duck is imagined as a human being (a young girl), who assumed the appearance of the bird as a result of sorcery. Hence, the duck is not allowed to be hunted: the one who kills it and thus violates the ban of the kin, commits a grave crime. In folklore, the duck is usually an adopted or an unloved daughter cursed by her stepmother. She has to assume the bird-like outline until getting married. The cycle of songs devoted to a duck and a hunter reflects the people's attitude to their kindred totems. The murderers of ducks are condemned in myths and the perpetrators of the crime are punished morally and physically. In some mythical songs, a young hunter does not kill the duck at her plea for mercy, but marries her instead. In other myths, a hunter (a married man) kills the duck, without paying attention to her request, and does this in spite of the fact that she warns him of many misfortunes (his family will perish, he will lose his crops), because she is not a duck, but a messenger of the Erzian Supreme God (Verepaz) (UPTMN 1963: 159). Sometimes the duck is considered to be the bird of the deity of woods, Forest Mother (Vir'ava). In myths, the duck is a donor of life in the first place, and a bird in the second. When a hunter kills this duck, he is struck by her moaning, the quantity of her blood and feather. In myths, the duck's actions are mainly connected with water, earth, air and sky. However, the mythoepic image of the duck, brooding eggs in its nest, is not only intrinsically Mordvinian, but also common among the Finnic peoples.

In Khanty mythology, according to one version of the Earth' origin, the latter was raised during the Deluge, as a red-cropped toadstool, by the bird Luli, species-wise a small lake loon (Mythology 2000: 163).

Gods and deities could appear in the shape of different birds, underlying their supernatural knowledge. The Moksha-Mordvinian Supreme God Shkai could change into a duck, an eagle and plunge in the heart of the Earth as a worm lest it would be tracked. The son of the Erzia-Mordvinian Supreme God, Nishkepaz, could turn into a pigeon, a swan, an eagle, a swallow etc., (Deviatkina 2002: 122) whereas his favourite bird is the swan (UPTMN 1963: 47) - god's messenger and the organiser of divine and human relations. In other myths, a hawk was the messenger of Nishkepaz, the son of the Supreme God of the Sun, with people.

The goddess-patroness of marriage, health, fertility, children, women in childbirth and infants, was Ange Patiai. She descended to the Earth in the aspect of a big bird with a long golden tail. At that moment grains fell onto the fields and meadows from her golden beak. The goddess could also assume the appearance of a snow-white dove, and from above she threw flowers for bees to gather honey, and bread-crumbs for hens (Pecherskii 1986: 82). In the calendar 
and ritual poetry, the Moksha-Mordvinian deity-patroness of fields (Paks'ava) is depicted as a grouse or a woman with long drooping hair; the deity-patroness of grain - Serava (mdM sera - 'grain', ava - 'woman, mother') - and the Erzian deity-patroness of fields, Norovava - were both depicted as skylarks. In Mordvinian tradition, in springtime, usually before ploughing, people baked small birds from pastry, called "skylarks", took them to the street (children did that) and cried: "Dear little skylarks, come and bring warm air!" In some villages, this tradition has survived until today.

There are also other birds dealt with in folklore: a prophetic raven with an iron beak and three swallows were helpers of the mythological hero Tiushtia (literally: a star). In addition, he himself could change into a swallow and rooster. The Khanty mythic hero Al'vali (the seventh son of the god Torum, an intermediary between gods and people) was sometimes depicted as a goose ( $(M y$ thology 2000: 106). The Mordvinian mythological character Varda (Deviatkina 2007: 109) could make birds work. In fairy-tales, the whereabouts of "living" water is known to those who could change into a bird and get to the place unreachable to common people.

Birds were also sacrificed at various magical ceremonies. The choice of the bird for sacrifice depended on the type of the ritual, however, hens were sacrificed more frequently. For example, nine hens were killed for the traditional feast Bab'ia kasha or Baban' kasha (literally: elderly women's porridge); in honour of the deity-patroness of harvest and farming (Norowawa) a yellow bird was sacrificed, and a black hen (UPTMN 1981, Ch. 3: 190-191) was sacrificed to Mastorava, the Mother of the Earth, during the ritual in her honour; at a house-warming party a black hen was thrown into the cellar for Kudava, the deity-patroness of the home, for propitiatory purposes. Hens were also sacrificed while laying the foundation of a church or town (after cutting a hen into four parts, people put each piece in the corners of the to-be-constructed building).

A special traditional village holiday - Saraz Ozks (mdM, mdE saraz - 'hen', ozks - 'praying, magical ceremony, holiday') - was performed after sowing the spring corn. This festivity was so named because hens were sacrificed at public praying (one hen from each house). The birds were killed on a river-bank, where the ceremony took place, and boiled in a joint cauldron. The blood was poured into a special pit where feathers and down were burnt and bones were thrown into the water. While praying, Mordvinians asked the Supreme God Shkai to grant a good harvest, health for people, fertility for cattle (Evsev'ev 1966: 400). In the myths of the Mordvinians in the Nizhni Novgorod region, a hen (saraz) became the favourite bird of goddess Ange Patiai, the Mother of Gods, because the hen was the only one, after the creation of the Earth, who 
did not refuse to fulfil the goddess's wish to lay an egg every day (Pecherskii 1986: 83).

When someone in the household died, the mistress immediately caught a hen in the yard, for protective purposes, and cut its head under the door of the shed or under the gate. Mordvinians threw hen's legs into the grave of a dead man and put a hen's head on the bosom of a dead woman, so that she could have eggs and chicks in the next world.

For the same protective purposes, various bans were imposed. Thus it was forbidden to bring a piece of bread back home from fieldwork (or the hens will die), or stones (hens will cease to lay eggs) or buttercup, the plant called "hen blindness" (or the hens will get blind). When hens were ill, a special magical praying was performed to Narava (mdM), the deity-patroness of creeping grass (Devyatkina 2004: 67). Mordvinians believed that if a piece of straw was stuck to a hen's tail or if the hen flew out of the smoke window of a bath-house, or if it crowed (UPTMN 2003: 154), the deceased was expected in the household. It was believed that a hen's crowing (foreboding a misfortune) could be neutralised, if the master of the house killed the hen, took out its throat, burnt it and threw the ashes to the wind. It was considered that if a hen laid eggs or hatched chicks secretly - the family would grow poor; if a hen crowed loudly, it signified a quarrel. At house-warming parties, a cock was let in the house and a hen was thrown into the cellar for the deity-patroness of the home - Kudava.

In the Gorodishche district of the Nizhni Novgorod region, Mokshans organised a holiday in honour of Neshkeava, the deity-patroness of the apiary and bee-hives, on the prophet Elijah's Day (August 2). It was obligatory to invite the Supreme God, and Neshkeava, and all deities-patronesses of woods to the feast, including the deities of everything that can be found in the forest (sometimes, e.g., even a fairy of an oak or a stump). A white goose was sacrificed. While praying to the deity of the apiary, people asked to increase the number of hives, to protect them from witches, evil people and damage.

A ritual ceremony to honour Ved'mastorpaz, the deity-patron of water on the whole Earth, was usually organised in September. A white goose, whose head was thrown into the water, was sacrificed to the deity for propitiatory purposes. The head was to be torn off, not cut off, the rest of the bird was eaten by the family. A goose was also sacrificed to Keche Iumo, the Mari God of the Sun (Toidybekova 2007: 103). In honour of the Mordvinian deity of fire - Tolava, a red rooster was sacrificed. Immolation of this bird was also performed in honour of the deity-patroness of kinship and family - Iurkhtava and the deity of bast and logs - Keren' Shochkon' paz, after the end of fieldwork and also before the beginning of ploughing, at the magical ceremony - Keret' ozks, devoted to a wooden plough. During the holiday devoted to White Birch - Inekelu $O z k s$, a ritual was performed whereby the heads and entrails of sacrificed birds 
(rooster, geese and hens) were laid beside the house threshold. Thereafter, all this was dug under the threshold or in the centre of the yard. It should be noted that prior to this, the person conducting the ritual tried to find out, by way of special actions, if the sacrifice (including the birds) appeased the gods and deities.

Birds also act as foretellers. The cuckoo ( $\mathrm{mdM} k u k u, \operatorname{mdE} k u k o$ ) is the most popular prophetic bird whose mythological origin is depicted differently in calendar folklore (Christmas carols, Shrove carols). According to one version, the cuckoo hatched out of the egg of the Great Bird's (mdE Ine Narmun'), or the Great Water Bird (mdE Poksh Ved' Narmun'), who built its nest, made of young girl's hair, in the large field, laid three eggs, hatched the younglings: a nightingale, a cuckoo and a skylark (the cuckoo usually comes out of the first or the second egg) (UPTMN 1981, Ch. 3: 68). According to other myths, the cuckoo is hatched by a heath-cock (or an unknown bird), who built its nest in the first grove, in the first tree, on the first branch, and laid three eggs out of which three nestlings hatched: a cuckoo, a nightingale, and a birdie (UPTMN 1981, Ch. 3: 68). The cuckoo is cuckooing in the first tree, on the first twig, bud, leaf. In the morning, cuckooing marked the beginning of a working day. The cuckoo's appearance is mythical - in Shrove carols it is depicted as a speckled bird with red booties on, its beak is gilded, its crest silky. In myths, the cuckoo was destined to become a domestic bird, however, at first it promised and then refused to fulfil the wish of Ange Patiai, the goddess-patroness of marriage, health, women in childbirth and infants, to lay eggs each day. Due to this, the cuckoo was punished and ousted from the human dwelling to the forest. In addition, the goddess did not allow the cuckoo to build its own nest and ordered it to lay its eggs in the nests of other birds. In order for the cuckoo to remember the broken promise, Ange Patiai made the cuckoo and its eggs speckled. Since then, it cuckoos sadly in the forest, missing a human dwelling-place. According to Mari materials, the cuckoo is deprived of its nest because it had built the nest on the Christian holiday of the Annunciation, when all works were strictly forbidden (Toidybekova 2007: 131).

Mordvinians believed that cuckoos were unborn children. There existed a ban to kill a cuckoo (or a baby will be killed). The children who died un-christened also became cuckoos (Deviatkina 1998: 139). In folklore, the deity-patroness of the woods, Vir'ava, is represented as a cuckoo. According to Heikki Paasonen (1997), the bird that flies in the twilight and resembles a cuckoo in its appearance and size is Shopacha (mdM) or Chopacha (mdE) (i.e. the ghost of the deceased, spectre, or devil).

In Khanty folklore, the cuckoo is represented as a supernatural creature or explained as follows: long time ago, the cuckoo was a woman who ran away from her disobedient children (Mythology 2000: 158). 
For the Mordvinians and other ethnoses, (in particular the Mari), cuckooing was a way of determining the period of one's own life. In this case, people would ask the bird: "Cuckoo, cuckoo, how long am I to live?", or as another option, young girls would sometimes as the cuckoo: "How many years are there left before I marry?” (Devyatkina 2004: 56)

The first cuckooing was associated with a number of omens and beliefs: cuckooing heard from the right side meant wealth all year round until the next cuckooing in spring, while cuckooing from the left side betokened hunger. Cuckooing in autumn meant a long and warm spring (Deviatkina 1994: 49). Cuckooing heard from the East was a good sign, from the West - a bad one. Cuckooing heard from the East promised bumper crops, from the South the birth of male babies, from the West - a young girl's death. Frequent cuckooing promised no good or, on the contrary, sunny weather. Cuckooing during the harvest was considered to have a magic meaning. If someone happened to hear it at that time, he/she was to turn in order to face the place from where cuckooing was heard. It was believed that in this case one would not have a sore throat until the next harvest. St. Peter's Day (July 12) was associated with the end of the period of cuckooing, and it was a bad omen to hear it after this day.

Particularly honoured and prophetic bird is the pigeon (mdM gul'nya, mdE gul'ka'). According to Mokshan views, it is shkaen' narmon'('divine bird'), an anthropomorphic creature. In several mythological tales the bird is dealt with as if it were a human being - loman' ('a man'). Due to this, eating doves and pigeons was strictly forbidden, it was a sin never to be forgiven. Likewise, there were taboos concerning the destruction of their nests, lest a pigeon or a dove would bring fire in its beak, set a house on fire and kill the family.

In calendar and ritual poetry (Christmas carols), the behaviour of pigeons and doves reminds one of a human activity: a pigeon (or a dove) bakes cakes of grains that it had brought in its beak, ground and sifted, spreads butter on them, and treats children by singing Christmas carols to these cakes. In mythological songs, a young girl turns into a dove. In wedding folklore, a dove symbolises the bride's tenderness and meekness (she is a domestic dove) (Deviatkina 1992: 24). In traditional Erzian wedding rituals, the twelfth layer of the main ritual pie luvon' kshi was decorated with two figures (four in the Ardatovo district) of pigeons made of pastry, the pigeons symbolising divine power and future peaceful life.

Even today, people believe that a dove flying through an open window means misfortune. If a dove only knocks at the window, it means a piece of news or a warning of danger (Deviatkina 1992: 61), especially of a house on fire. Doves and pigeons were also referred to in fortune-telling practices. The weather 
was predicted by the flight of pigeons set free on the Epiphany (to which side the pigeons would fly, from there rain would come) (UPTMN 2003: 113).

Mordvinian mythological worldview reflects the image of the pigeon in embroidery as well. In particular, some patterns on shirts resemble the shape of pigeon's traces (mdM gul'kan'pil'gekit) or bird wings (mdM patsianiat).

Likewise, there are infrequent references of cursed birds, in particular, the buzzard (mdE panzei, panzi). According to a legend, after the creation of the world, the God ordered all birds to dig an individual well for each of them to wash there. Everyone obeyed, apart from the buzzard who was absent at the moment. When it finally arrived it decided to use trickery and get a well for free - thus, the buzzard suggested the crow should go and wash itself of silt to appear in front of the God clean. Meanwhile, the buzzard soiled itself with silt, flew to God before the crow and said that it had also dug a well and pointed to that of crow's as if this was its own. God cursed the buzzard for deception and prohibited the bird from drinking water from rivers, lakes and wells. Since that time the bird is able to slake its thirst only with rainwater and dew, and when it has not been raining for a long time, the buzzard begins weeping and asks God for water (UPTMN 1983: 190).

A number of proverbs and sayings have emerged on the basis of the abovementioned legend, e.g., Mokshas-Mordvinians say of those, who like to make use of other people's work: Panzit' kondiaks vadend'sy priants i miar'gi: eshit' mon shuvine 'Like a buzzard who soils its head and says: I have dug a well'.

Images of birds were used in some incantations, e.g., against eyesore according to a mythical plot there is in an enormous elm by the sea where Ine Narmun' (mdE 'great bird') is sitting and pecking the disease to pieces with her beak (UPTMN 1981, Ch. 3: 203).

Birds as foretellers of weather. Mythological folk beliefs are also reflected in popular omens about the weather, associated with the behaviour of birds. People watched the time of birds' arrival: Kda pozdna saikht' narmottne, kizos' uli kuvaka (mdM 'If birds arrive late, summer will be long'); behaviour: Kda narmottne liendikht' mekovasu, pizem tui (mdM 'If birds fly in a bustling manner, it will rain'); location: Kukus' kukai kos'ke shufta priasa - iakshama uli ( $\mathrm{mdM}$ 'If a cuckoo is cuckooing in a dry tree, it means cold weather') (Deviatkina 1994: 49). Cold weather, warm weather, and rain are predicted by the birds' cry, behaviour or play: rain was expected when varsikhne piak karknaikht' (mdM 'crows croak loudly'), chavkatne nalkhksikht'(mdM 'jackdaws gambol'), kir'khksne modasa esheliaikht' (mdM 'sparrows bathe in dust'), oziakatne veli pryt' (mdE 'sparrows fly to a village'). Fine weather was expected when gul'niatne moraikht' (mdM 'pigeons coo'), kir'khksne piak chil'niaikht' (mdM 'sparrows chirp loudly') (UPTMN 2003: 76-78). 
Scientists have ascertained that the presence of special air bags and cavities in the bodies of birds allow them to feel changes in the atmospheric pressure, e.g., their flying low usually precedes bad weather. Mordvinians used to determine, by the appearance of birds, whether the coming spring would be warm or cold: Kda vir' iaksiarkne saikht' af kuiat, tundas' uli liambe (mdM 'If wild ducks arrive skinny, the coming spring will be warm'), and on the contrary Kda vir' iaksiarkne saikht' kuiat, tundas' uli iakshama ('If wild ducks arrive fat, the coming spring will be cold'). Early arrival of chavkatnen' $i$ zhavoronkatnen' ('jackdaws and skylarks') meant warm spring. Likewise, the particular behaviour of birds could predict a snowstorm sez'ganos' kekshni krysha alov (mdE 'a magpie hides itself under the roof') or snowfall: Alga etaikht' vir'matsikhne kurok lov prai (mdM 'Wild geese fly low, snow will fall soon'). The coming of colds was expected when migrating birds flew away early: Buti lokseitne tuit' rana seksnia, boikasto syt' iakshamotne' (mdE 'If swans fly away at the very beginning of autumn, cold weather will come quickly afterwards') (UPTMN 2003: 79).

Quite remarkable is the behaviour of domestic birds: Sarazos' tarksesynze es' tolganzo-pogodan' polavtomanten' (mdE 'If hens clean feathers, it means bad weather'); Buti saraztne lisnit' pizemen' shkasto, kurok pizemes' iuty ( $\mathrm{mdE}$ 'If hens come out during the rain, the rain will be over soon'). As an omen of rain, hens pinch their feathers, bathe in dust, hide themselves in the daytime. As a sign of the autumn coming, they clean their feathers. Predicting a cold winter, they drop their feathers in autumn; if a hen dropped her tail, she would not lay eggs anymore. People also believed that when a hen wetted her leg on St.

Evdokia's Day (i.e. that it thawed a little), summer would be fine (UPTMN 2003: 112). By untimely crowing of cocks, people expected the arrival of warmth: Atiakshtne karmit' moramo ran'she - lembes ( $\mathrm{mdE}$ 'Cocks begin to crow earlier than usual, it means warmth'); Tialonda iliat' atiakshne kukoriaikht'-liambondi (mdM 'Cocks crow at daytime in winter, it means warmth').

The omens about rain, associated with the behaviour of sparrows, are widespread among the peoples of the Volga region (Mordvinians, Maris, Chuvashs, Russians).

\section{ABBREVIATIONS \\ $\mathrm{mdE}=$ Erzian language \\ $\mathrm{mdM}=$ Mokshan language}




\section{REFERENCES}

Deviatkina, Tatiana 1992. Mokshanskie suadebnye obryady i pesni. [Mokshan Marriage Rituals and Songs.] Saransk : Mordovsk. knizhoe izdatel'stvo.

Deviatkina, Tatiana 1994. Narodnye primety mordvy-mokshi. [Mokshan and Erzian Folk Signs.] Saransk: Izdatel'stvo Mordovskogo universiteta.

Deviatkina, Tatiana 1998. Mifologiia mordvy. Entsiklopediia. [Mordvinian Mythology. Encyclopaedia.] Saransk: Mordovskoe knizhnoe izdatel'stvo.

Deviatkina, Tatiana 2002. Moksherzian' mifologiias'. [Mosha-Erzian Mythologies.] Tartu: Estonian Literary Museum. http://haldjas.folklore.ee/rl/folkte/sugri/ mordva/ersa/myto2/koi-8/, last accessed on 20 August 2011.

Deviatkina, Tatiana P. 2007 [1998, 2006]. Mifologiia mordvy. Entsiklopediia. [Mordvin Mythology: Encyclopaedia.] Saransk: Krasnyi oktiabr.

Devyatkina, Tatiana 2004. Mordvinian Mythology. Ljubljana: SRZ/SAZU.

Evsev'ev, M. E. 1966. Izbrannye trudy. T.5 Mordovskaya svadba. [Selected works. Vol. 5. Mordvinian wedding.] Saransk: Mordovskoe knizhnoe izdatel'stvo.

Harva, Uno 1952. Die religiosen Vorstellungen der Mordwinen. Folklore Fellows Communications 142. Helsinki: Academia Scientarum Fennica.

Mythology 2000 = Mifologiia khantov. [Khanty Mythology.] Tomsk: Izdatel'stvo Tomskovo Universiteta.

Myths 1994 = Mify narodov mira. Entsiklopediia. Vol. 2. [Myths of the Peoples of the World. Encyclopaedia.] Moscow: Rossiiskaia entsiklopediia.

Pecherskii, Andrei 1986. Ocherki mordvy. [Mordva:An Overview.] Saransk: Mordovskoe knizhnoe izdatel'stvo.

Paasonen, Heikki 1977. Mordwinische Volksdichtung 5. Helsinki: Suomalais-Ugrilaisen Seuran Toimituksia.

Toidybekova, Lidiia 2007. Mariiskaia mifologiia: Etnograficheskii spravochnik. [Mari Mythology: Ethnographic Reference.] Ioshkar-Ola: MPIK.

UPTMN 1963 = Kavtaskin, L. S (ed.) Ustno-poeticheskoe tvorchestvo mordovskogo naroda. Tom 1. [Oral-Poetic Folklore of the Mordvinian People. Vol. 1.] Epicheskie i liroepicheskie pesni. [Epic and Lyroepic Songs.] Saransk: Mordovskoe knizhnoe izdatel'stvo.

UPTMN 1981 = Imaikina, V. L. \& Samorodov, K.T. (eds.) Ustno-poeticheskoe tvorchestvo mordovskogo naroda. Tom 7. Ch. 3. [Oral-Poetic Folklore of the Mordvinian People. Vol. 7. Ch. 3.] Kalendarno-obryadovye pesni $i$ zagovory. [Calendar and Ritual Songs and Incantations.] Saransk: Mordovskoe knizhnoe izdatel'stvo.

UPTMN 1983 = Sedova, L. V. (ed.) Ustno-poeticheskoe tvorchestvo mordovskogo naroda. Tom 10. [Oral-Poetic Folklore of the Mordvinian People. Vol. 10.] Legendy, predaniya, bylichki. [Legends, Tales, Short Epic Stories.] Saransk: Mordovskoe knizhnoe izdatel'stvo.

UPTMN 2003= Deviatkina, Tatiana (ed.) Ustno-poeticheskoe tvorchestvo mordovskogo naroda. Tom 12. [Oral-Poetic Folklore of the Mordvinian People. Vol. 12.] Narodnye primety mordvy. [Folk Signs of the Mordvinian People.] Saransk. Krasnyi oktiabr. 